\title{
Measuring Customer Satisfaction on Small-Scale Sport Event: A Case Study of The Sport Event Organizer Subject's Final Project
}

\author{
Billy Castyana ${ }^{1}$, Tandiyo Rahayu ${ }^{2}$, Rumini $^{3}$, Mugiyo Hartono ${ }^{4}$, \\ Dwi Gansar Santi Wijayanti ${ }^{5}$, Wahyu Ragil Kurniawan ${ }^{6}$ \\ \{billycastyana@mail.unnes.ac.id ${ }^{1}$, tandiyorahayu@mail.unnes.ac.id ${ }^{2}$, rumini@mail.unnes.ac.id ${ }^{3}$ \} \\ Department of Physical Education Universitas Negeri Semarang, Semarang, Indonesia ${ }^{1,2,3,4,5,6}$
}

\begin{abstract}
The aim was to measure the customer satisfaction on small-scale sport event conducted by students. This quantitative descriptive study was conducted using survey method with population came from the participants of sport events throughout Central Java and were chosen by accidental sampling with 141 respondents. Survey consists of Tangible, Empathy, Responsiveness, Reliability, and Assurance in the form of checklist by using Likert scale 1 to 4 . From the results of data processing, researchers found that $75 \%$ of participants said the committee is reliable. Then $75.18 \%$ of participants stated the organizer is responsive. The data also shows $76.60 \%$ of participants mention how assure they are due to organizing committee could build a good trust among them. Then $77.48 \%$ of participants said that the emphaty addressed by the committee was in accordance with the participants' expectations and $80.32 \%$ of the tangible factors were given by organizer make participants will participate again.
\end{abstract}

Keywords: sport event organizer, customer satisfaction, sport management.

\section{Introduction}

Sport events are an entertaining physical activities that have a creative and complex character, including an impact on improving tourism and socio-economy for a region[1]. Various countries are currently competing to host large-scale sport events, such as the Olympics, Asian Games, World Cup, etc. However, many do not pay attention that holding small-scale events has the potential to have a large impact on local communities[2]. The small-scale sport event itself is a sporting event which is organized by involving a small sports fan base that is held routinely at both the regional and national levels[3]. Small-scale sports events like this are able to provide benefits in the local economy, tourism, cheap entertainment for the community, and enhancing community pride[4]. Small-scale events also have the advantage of being easy to manage and the implementation does not incur large costs so that events like this can avoid the negative impact of organizing mega events[2]. To maximize this potential, the organizing committee must be able to provide satisfaction during the event. In its implementation, the most benefi- 
cial thing is to give satisfaction to the sports fans because until now sports fans have a big role in the success of the event[5]. They are willing to spend money to be able to watch directly or indirectly through other media.

From previous studies, it can be concluded that customer satisfaction is an evaluation of what is felt by customers and whether the services provided are in line with expectations[6]. Customer satisfaction is the key to the loyalty of sports fans and this will make them provide a beneficial relationship with the event organizer[7]. In addition, customer satisfaction can also be interpreted as how customers evaluate the performance of event organizers and later the results of these evaluations can show how the level of customer satisfaction[8]. According to that statement, it means the event organizer must improve the quality of service and set prices according to the services received so that customers will be satisfied[9]. If this can be realized, it will affect the desire to re-join the event, invite more people to participate, bring up positive reviews, so that the event organizer can compete with other event organizing competitors[10]. It should be noted that the ability to be able to provide satisfaction to customers will determine the difference between one event with another event and can build customer loyalty relationships[11].

To build customer satisfaction, sport event organizer must understand how to provide services to customers, this is called service quality. When viewed from an economic point, the services provided must meet customer desires because the service will determine how the evaluation provided by the customer on their level of satisfaction[12]. In addition, from a social standpoint, services must be provided to customers on reasonable grounds[6]. From this opinion, it can be concluded that service is an activity that provides customer support systems, handling complaints, speed in handling complaints, ease in reporting complaints, and friendliness in receiving complaints[8]. Previous research has shown that when customers don't get good service when they report complaints, that's when they start switching to other brand[13]. In addition, the friendly and polite attitude of the organizers of events related to service will give a positive impression that can make customers satisfied[14].

Quality of service has ten requirements to be met, namely reliability, responsiveness, tangibles, communication, credibility, security, competence, courtesy, ability to understand customers, and customer access to services. However, if you look at the service quality scale (SERVQUAL), there are five dimensions that must be met, including reliability, responsiveness, assurance, empathy and tangibles[15] This measurement model is a tool commonly used to measure service levels and differences in customer satisfaction. Reliability is an ability to deliver what the organizer promises to customers. Responsiveness is how the organizer is prepared to provide good service. Assurance is the organizer's ability to build trust in customers. Emphaty is caring and prioritizing service to customers and how organizers are able to translate what customers want. The last dimension is Tangible, this dimension shows how facilities are used, how to communicate, and how to provide services to customers[16]

Since 2017, Department of Physical Education, Universitas Negeri Semarang includes material about sport event organizers as a part of curriculum. The final task of this course, students are required to be able to conduct small-scale sport events in various regions in Central Java. Over the past two years, the success of students in organizing sport events has been extraordinary because in addition to the knowledge they get directly in the field, they also get financial benefits ranging from $\mathrm{Rp}$. 750,000 to Rp. 
$11,000,000$. This certainly cannot be separated from the performance carried out by the committee to make customer satisfied. With many sports events had been conducted by students, it needs to have a further study to understand the customer satisfaction within the event. This research conducted to know how satisfy consumers are with the performance of the existing committee, whether the implementation of the event is in accordance with the expectations of the participants, and whether the services provided are good enough. This study aims to measure the customer satisfaction on small-scale sport event conducted by students so that it becomes a feedback for the implementation of the next event.

\section{$2 \quad$ Methods}

This quantitative descriptive study was conducted using survey method. Population came from the participants of sport events throughout Central Java which conducted by Physical Education students and were chosen by accidental sampling with 141 respondents. They were asked using a 4-point Likert Scale modification of SERVQUAL instrument consist of reliability, responsiveness, assurance, empathy and tangible, which was adopted with a slight modification[17].

Table 1. Servqual questionnaire.

\begin{tabular}{|c|c|}
\hline Indicators & Question \\
\hline \multirow[t]{5}{*}{ Resposiveness } & The committee is responsive in providing services during the event \\
\hline & The committee responses all complaints regarding the activities friendly \\
\hline & $\begin{array}{l}\text { The committee is able to provide solutions to every problem regarding the } \\
\text { event }\end{array}$ \\
\hline & $\begin{array}{l}\text { The committee provides the best service from the beginning to the end of } \\
\text { the event }\end{array}$ \\
\hline & The committee is running event on schedule \\
\hline \multirow[t]{5}{*}{ Assurance } & The event is going well \\
\hline & The services provided by the committee are good \\
\hline & The committee is polite during the event \\
\hline & The committee is friendly towards all participants \\
\hline & The committee can be trusted \\
\hline \multirow[t]{5}{*}{ Tangible } & Existing facility supports the ongoing sport event. \\
\hline & Existing facility is sufficient to conduct sport event. \\
\hline & The Sport Hall is quite spacious and sturdy. \\
\hline & The location of sport hall is quite strategic. \\
\hline & All committees look neat, attractive and polite. \\
\hline \multirow[t]{5}{*}{ Emphaty } & It is easy to register as a participant \\
\hline & There is a clear explanation related to facility \\
\hline & The committee provides good service to participants \\
\hline & $\begin{array}{l}\text { In general the committee provided the needs of the participants during the } \\
\text { event }\end{array}$ \\
\hline & Participants can give feedback both written and oral \\
\hline \multirow[t]{3}{*}{ Reliability } & $\begin{array}{l}\text { The committee always helps participants in facing difficulties during the } \\
\text { event }\end{array}$ \\
\hline & The committee is able to solve problems quickly \\
\hline & The committee is responsible for all activities \\
\hline
\end{tabular}


The committee is fast and proper in providing services during the event The committee provides clear information to participants

Before the survey began, Physical Education students already conducted sport event at 7 regions in Central Java. The respondents were received the questionnaire after they finished their participation on the entire series of events, and during they filled out the questionnaire they were accompanied by the research team to assist if there were any difficulties.

\section{$3 \quad$ Result and discussion}

\subsection{Result}

After data collection was carried out in 7 regions, namely Banyumas, Tegal, Kendal, Blora, Kudus, Temanggung, and Wonosobo, the data was then processed to get an overview of the level of customer satisfaction at the event. From the results of data analysis, researchers found that $76.91 \%$ participants satisfied with the organizer. However, if we focused on each indicators, $75 \%$ of participants said the committee is reliable. Then $75.18 \%$ of participants stated the organizer is responsive. The data also shows $76.60 \%$ of participants mention how assure they are due to organizing committee could build a good trust among them. Then $77.48 \%$ of participants said that the emphaty addressed by the committee was in accordance with the participants' expectations and $80.32 \%$ of the tangible factors were given by organizer make participants will participate again.

Table 2. Servqual Percentage Analysis.

\begin{tabular}{lcc}
\hline \multicolumn{1}{c}{ Factors } & Average & Percentage (\%) \\
\hline Responsiveness & 3.00 & 75 \\
Assurance & 3.01 & 75.18 \\
Tangible & 3.06 & 76.60 \\
Emphaty & 3.10 & 77.48 \\
Reliability & 3.21 & 80.32 \\
\hline
\end{tabular}

\subsection{Discussion}

In the data shown in table 1 , it can be seen how satisfying the implementation of sports events conducted by Physical Education students. This satisfaction is inseparable from the factors were successfully met by the committee, such as committee performance, event execution, service quality, and committee attitudes, which eventually made the participants would like to participate again. In addition, these results also have interference from lecturers who guide and control them. How students learn the science of organizing sports events in class and applying them in the field is an integral part.

Consumer satisfaction is closely related to the suitability of service between expectations and reality that consumer receive[18]. Consumers can feel satisfaction if what is promised and expected by them can be fulfilled. From the five dimensions it can be seen that customer satisfaction has a high percentage. However, responsiveness has a lowest 
percentage among them, it means that the event organizer had not prepared the activity properly so there were still problems in service to customers. There was also time when the committee confused when there were questions from customers. To improve it, organizer needs to conduct a training so that the committee is ready when faced with conditions on the ground. This training has an important role in the achievement of organizing events because it can make the committee work more efficiently and effectively[19]. Especially when the committee that works does not have much experience even though they already have knowledge, but the quality of the performance depends on three things, namely experience, knowledge, and management[20].

As the highest percentage of customer satisfaction, the reliability is shown that the committee succeeded in realizing the expectations of the customers. Reliability has two important factors namely consistency and dependability. Consistency shows how the committee can work together in a single unit in a compatible manner and make the quality of service the same standard. Dependability shows the certainty of the committee to be able to show services in accordance with customer expectations and increase trust in the organizer. From these two factors, it can be found the reasons why customers are satisfied with the performance of the committee[21].

In the first factor, consistency, the committee proves that they have the same standard in treating customers. Starting from the beginning of registration and the same payment system until the time of the event where the committee made a group chat as a communication medium so that all customers get the same information. Based on the second factor, dependability, committee showed good service when customers feel confused in the payment process, registration, until when they have a complaint. This made the committee succeeded in building customer trust. On the opposite hand committee ought to perceive in each event, issues and protests from participants are inevitable. The ability of the committee to resolve issues quickly is also a matter of thought whether participants would like to rejoin the event or not. The committee should be able to show participants that they are reliable individuals in breakdown problems quickly. They need to make sure the neutrality in providing solutions and be ready to be liable for all choices taken. Therefore, the committee is needed to possess a sense of belonging so all committees would be one in solving issues. The committee is additionally needed to not offer solutions to issues that do not seem to be their domains due to inaccurate info that causes additional issues. By delegating the matter to the correct committee, it will provide the proper answers and therefore the performance showed by the committee is better.

Performance also has a relation with how committee will run the event. During the event the committee must ensure that the rundown event that has been shared with the participants is carried out appropriately. If there is a delay or change in schedule, the committee must notify the participants as soon as possible so that participants do not wait or are late to attend. Therefore, the committee must have a Liaison Officer (LO) to become a contact person. Besides, participants also expect that there will be a suitability of service with the price paid to become a participant. Appropriate exchange of values is important because the committee must hold the principle even though the customer is wrong, they are always right. The committee has the responsibility to provide services to the maximum extent possible in accordance with the amount of value paid by participants. It is the power to meet the committee guarantees properly and equally, like customer service is not difficult, particularly throughout registration and simply to urge info. Therefore, the committee must have good communication among them and with the 
participants, such as no different information between committee and giving warm attitude to participants when they ask and give complain, especially information regarding the facilities provided by the institution and those available on venue.

Another thing that must be considered is the committee's attitude to the participants, including how the committee reacts to the criticism and suggestions from participants. The committee must be friendly to all participants without exception, because participants are customers and the sustainability of an event depends on customer satisfaction. The committee must have empathy for the participants who are not just politeness and friendliness in serving customers, but rather a commitment to customers, willingness to understand their needs carefully, and trying to fulfill them. If applied in the event, it can take the form of attention to customer complaints regardless of social status.

This research is part of research about factors that influence the performance of sport event organizers. This research was conducted to provide input on how sports events should be held and how to become a good sports event committee.

\section{References}

[1] Bjelac, Z., \& Radovanovic, M. (2003). Sports events as a form of tourist product, relating to the volume and character of demand. Journal of Sport tourism, 8(4), 260-269.

[2] Tzetzis, G., Alexandris, K., \& Kapsampeli, S. (2014). Predicting visitors' satisfaction and behavioral intentions from service quality in the context of a small-scale outdoor sport event. International Journal of Event and Festival Management.

[3] Gibson, H. J., Willming, C., \& Holdnak, A. (2003). Small-scale event sport tourism: Fans as tourists. Tourism management, 24(2), 181-190.

[4] Gibson, H. J., Kaplanidou, K., \& Kang, S. J. (2012). Small-scale event sport tourism: A case study in sustainable tourism. Sport management review, 15(2), 160-170.

[5] Lee, J. S., \& Kang, J. H. (2015). Effects of sport event satisfaction on team identification and revisit intent. Sport Marketing Quarterly, 24(4), 225.

[6] Hanif, M., Hafeez, S., \& Riaz, A. (2010). Factors affecting customer satisfaction. International research journal of finance and economics, 60(1), 44-52.

[7] Eshghi, A., Haughton, D., \& Topi, H. (2007). Determinants of customer loyalty in the wireless telecommunications industry. Telecommunications policy, 31(2), 93-106.

[8] Kim, M. K., Park, M. C., \& Jeong, D. H. (2004). The effects of customer satisfaction and switching barrier on customer loyalty in Korean mobile telecommunication services. Telecommunications policy, 28(2), 145-159.

[9] Gustafsson, A., Johnson, M. D., \& Roos, I. (2005). The effects of customer satisfaction, relationship commitment dimensions, and triggers on customer retention. Journal of marketing, 69(4), 210-218.

[10] Anderson, E. W., Fornell, C., \& Mazvancheryl, S. K. (2004). Customer satisfaction and shareholder value. Journal of marketing, 68(4), 172-185.

[11] Deng, Z., Lu, Y., Wei, K. K., \& Zhang, J. (2010). Understanding customer satisfaction and loyalty: An empirical study of mobile instant messages in China. International journal of information management, 30(4), 289-300.

[12] Turel, O., \& Serenko, A. (2006). Satisfaction with mobile services in Canada: An empirical investigation. Telecommunications policy, 30(5-6), 314-331.

[13] Ahn, J. H., Han, S. P., \& Lee, Y. S. (2006). Customer churn analysis: Churn determinants and mediation effects of partial defection in the Korean mobile telecommunications service industry. Telecommunications policy, 30(10-11), 552-568.

[14] Söderlund, M., \& Rosengren, S. (2008). Revisiting the smiling service worker and customer satisfaction. International Journal of Service Industry Management. 
[15] Loke, S. P., Taiwo, A. A., Salim, H. M., Downe, A. G., \& PETRONAS, U. T. (2011). Service quality and customer satisfaction in a telecommunication service provider. In International conference on financial management and economics (Vol. 11, No. 2, pp. 2329).

[16] Bhat, M. A. (2012). Tourism service quality: A dimension-specific assessment of SERVQUAL. Global Business Review, 13(2), 327-337.

[17] Theodorakis, N. D., Kaplanidou, K., \& Karabaxoglou, I. (2015). Effect of event service quality and satisfaction on happiness among runners of a recurring sport event. Leisure Sciences, 37(1), 87-107.

[18] Hult, G. T. M., Cavusgil, S. T., Calantone, R. J., Day, G., Wansink, B., van Ittersum, K., ... \& Lehmann, D. (2003). Knowledge as a strategic resource in logistics and purchasing (pp. 120). Marketing Science Institute.

[19] Latham, G. P. (2011). Human resource training and development.

[20] Amisano, C. (2010). eHow contributer "Relationship between traning and employee performance". Available on the website: http://hrcouncil. ca/hr-toolkit/learningimplementing. cfm.

[21] Gunawardane, G. (2011). Reliability of the internal service encounter. International Journal of Quality \& Reliability Management. 